\title{
Chemical and hydrophysical attributes of an Oxisol under coffee intercropped with brachiaria in the Cerrado
}

\author{
Omar Cruz Rocha(1), Maria Lucrécia Gerosa Ramos(2), Adriano Delly Veiga(1), Antonio Fernando Guerra(3), \\ Gabriel Ferreira Bartholo(3), Gustavo Costa Rodrigues ${ }^{(4)}$ and Juliano Escobar da Silva( ${ }^{(2)}$
}

\begin{abstract}
(1)Embrapa Cerrados, BR-020, Km 18, Caixa Postal 08223, Planaltina, CEP 73310-970 Brasília, DF, Brazil. E-mail: omar.rocha@embrapa.br, adriano.veiga@embrapa.br (2)Universidade de Brasília, Faculdade de Agronomia e Medicina Veterinária, Campus Universitário Darcy Ribeiro, Instituto Central de Ciências, Ala Sul, Caixa Postal 04508, CEP 70910-970 Brasília, DF, Brazil. E-mail: lucrecia@unb.br, juliano.escobar@hotmail.com ${ }^{(3)}$ Embrapa Café, Parque Estação Biológica, Avenida W3 Norte (Final), CEP 70770-901 Brasília, DF, Brazil. E-mail: antonio.guerra@embrapa.br, gabriel.bartholo@embrapa.br ${ }^{(4)}$ Embrapa Informática Agropecuária, Avenida André Tosello, no 209, Campus da Unicamp, Barão Geraldo, CEP 13083-886 Campinas, SP, Brazil. E-mail: gustavo.rodrigues@embrapa.br
\end{abstract}

\begin{abstract}
The objective of this work was to evaluate the effect of irrigation and of the presence of brachiaria (Urochloa decumbens) between coffee (Coffea arabica) rows on coffee yield and on chemical and hydrophysical attributes of a Typic Haplustox. The study was conducted in the Cerrado region in Planaltina, Brasília, DF, Brazil, in a randomized complete block design, arranged in split-split plots, with four replicates. Water regimes (irrigated or rainfed) were assigned to the main plots, inter-row management systems to the subplots, and soil layers to the sub-subplots. The following soil attributes were determined: total organic carbon, total nitrogen, $\mathrm{C} / \mathrm{N}$ ratio, carbon and nitrogen stocks, bulk density, aggregate stability, total porosity, macroporosity, low-retention microporosity, remaining microporosity, criptoporosity, and total and readily-available water, besides coffee yield. Irrigation of coffee plants, associated with brachiaria intercropped as a cover crop, increased coffee yield and favored chemical and hydrophysical soil attributes, improving soil structure and its ability to store water. Irrigation favors organic carbon stocks in the upper soil layers, whereas brachiaria favors soil physical attributes related to water availability to coffee.
\end{abstract}

Index terms: Coffea arabica, Urochloa decumbens, cover crops, soil physical quality, soil porosity, water availability.

\section{Atributos químicos e físico-hídricos de um Latossolo sob cafeeiro consorciado com braquiária no Cerrado}

\begin{abstract}
Resumo - O objetivo deste trabalho foi avaliar o efeito da irrigação e da presença de braquiária (Urochloa decumbens) nas entrelinhas do café (Coffea arabica) sobre a produtividade do cafeeiro e sobre os atributos químicos e físicohídricos de um Latossolo Vermelho distrófico típico. O ensaio foi conduzido na região do Cerrado, em Planaltina, Brasília, DF, em delineamento de blocos ao acaso, com parcelas sub-subdivididas e quatro repetições. Foram alocados os regimes hídricos (irrigado ou não irrigado) nas parcelas, os sistemas de manejo das entrelinhas nas subparcelas e as camadas de solo nas sub-subparcelas. Os seguintes atributos do solo foram determinados: carbono orgânico total, nitrogênio total, relação $\mathrm{C} / \mathrm{N}$, estoques de carbono e nitrogênio, densidade do solo, estabilidade de agregados, porosidade total, macroporosidade, microporosidade de baixa retenção, microporosidade remanescente, criptoporosidade, e disponibilidade de água total e de água prontamente disponível, além da produtividade de café. A irrigação do cafeeiro, associada ao consórcio com braquiária como planta de cobertura, aumentou a produtividade de café e favoreceu os atributos químicos e físico-hídricos do solo, o que melhorou a estrutura do solo e a sua capacidade em armazenar água. A irrigação favorece o estoque de carbono nas camadas superficiais do solo, enquanto a braquiária favorece os atributos físicos do solo relacionados à disponibilidade de água para o cafeeiro.
\end{abstract}

Termos para indexação: Coffea arabica, Urochloa decumbens, plantas de cobertura, qualidade física do solo, porosidade do solo, disponibilidade de água.

\section{Introduction}

The coffee (Coffea arabica L.) crop is expanding in the Cerrado (Brazilian savanna) region of Brazil, with a production of 5.9 million bags in 2013, which corresponds to $15.4 \%$ of the Brazilian production (Acompanhamento..., 2014). A major climatic characteristic of the Cerrado biome is a well-defined dry season during winter and the recurrent occurrence of dry spell periods during the rainy season. Therefore, irrigation is an essential practice for achieving high yields, profitability, and high quality coffee grains (Bonomo et al., 2008; Lima et al., 2008; Costa et al., 2013; Sakai et al., 2013). 
The development and expansion of the coffee crop in the Cerrado occurred predominantly in Oxisols (Eberhardt et al., 2008), a soil class that covers over $50 \%$ of this region. Despite the fact that this soil class has favorable management characteristics, it shows strong chemical and hydrophysical limitations.

Aggregate stability is reported to decrease in coffee production systems without the use of organic residues in the inter-rows (Nunes et al., 2010), jeopardizing soil structure. Moreover, Bicalho (2011) concluded that coffee irrigation in the Cerrado region favored aggregation and total organic carbon (TOC) on soil surface, when associated with cover crops in between coffee rows.

Rocha et al. (2014) observed that brachiaria, Urochloa decumbens (Stapf) R.D. Webster, improves soil quality due to the direct action of its roots on soil structure. This forage is very used in the Cerrado region, but it is commonly considered an invasive and potentially competitive weed to the coffee crop (Magalhães et al., 2012; Siqueira et al., 2015). However, its high adaptability, appropriate architecture for intercropping in coffee production system, easy natural reseeding, hardiness, easy maintenance, and resistance to mechanization are features that qualify this species as a potential cover crop in the inter-rows of coffee trees (Wutke et al., 2014).

The objective of this work was to evaluate the effect of irrigation and of the presence of brachiaria (Urochloa decumbens) in between coffee (Coffea arabica) rows on coffee yield and on chemical and hydrophysical attributes of a Typic Haplustox.

\section{Materials and Methods}

The experimental area is located at Embrapa Cerrados $\left(15^{\circ} 35^{\prime} 4^{\prime \prime} \mathrm{S}, 47^{\circ} 43^{\prime} 51^{\prime \prime} \mathrm{W}\right.$, at 1,009-m altitude) in Planaltina, Brasília, DF, Brazil. Soil attributes were studied in a Latossolo Vermelho distrófico típico, i.e., a Typic Haplustox, and an area with native Cerrado vegetation was used as reference (Table 1). From 2000 to 2007, the experimental area was covered with brachiaria, but it had not been used as pasture. On December 2007, 'Catuaí Vermelho IAC 144' coffee seedlings were planted with $3.50 \mathrm{x} 0.70-\mathrm{m}$ spacing. At planting, fertilization consisted of $120 \mathrm{~g}$ triple superphosphate, $50 \mathrm{~g}$ magnesium thermophosphate (Yoorin-Mineração Curimbaba Ltda., Poços de Caldas, MG, Brazil), and $24.5 \mathrm{~g}$ fritted trace elements (FTE) per plant. Previously, $2 \mathrm{Mg} \mathrm{ha}^{-1}$ dolomitic limestone were broadcasted and incorporated in the whole area, in order to increase soil base saturation to $50 \%$. In the following years, the nutritional management of the crop was carried out according to Guerra et al. (2007).

Two water regimes were evaluated: irrigated, according to the recommendations of Guerra et al. (2007); and a rainfed treatment. The irrigations were discontinued from the end of June until the beginning of September in each year, in order to induce uniform flowering after resuming irrigation (Guerra et al., 2007). Soil water content was measured with the soil moisture sensor ML1 (Delta-T Devices Ltd., Cambridge, United Kingdom).

Inter-row management systems consisted of brachiaria intercropped in between rows of coffee plants, and of a traditional planting system without brachiaria. In the brachiaria-covered treatment, cover plants were mechanically cut when they reached 0.60 $\mathrm{m}$ height; and, in the traditional treatment, the soil was kept free of brachiaria or any other weed by manual cleaning. Plant residues remained on the soil surface.

Table 1. Chemical and hydrophysical attributes of a Latossolo Vermelho distrófico típico, i.e., a Typic Haplustox, from the experimental area and from an adjacent native Cerrado (Brazilian savanna) area considered as a reference, at 0.0 to $0.2-\mathrm{m}$ soil depth.

\begin{tabular}{|c|c|c|}
\hline Soil attribute ${ }^{(1)}$ & Native Cerrado & Experimental area \\
\hline $\mathrm{pH}_{\text {water }}$ & 4.9 & 5.2 \\
\hline $\mathrm{P}_{\text {Mehlich-1 }}\left(\mathrm{mg} \mathrm{dm}^{-3}\right)$ & 1.6 & 1.4 \\
\hline $\mathrm{K}^{+}\left(\mathrm{mg} \mathrm{dm}^{-3}\right)$ & 33.0 & 61.2 \\
\hline $\mathrm{Ca}^{2+}\left(\mathrm{cmol}_{\mathrm{c}} \mathrm{dm}^{-3}\right)$ & 0.3 & 2.3 \\
\hline $\mathrm{Mg}^{2+}\left(\mathrm{cmol}_{\mathrm{c}} \mathrm{dm}^{-3}\right)$ & 0.2 & 0.8 \\
\hline $\mathrm{Al}^{3+}\left(\mathrm{cmol}_{\mathrm{c}} \mathrm{dm}^{-3}\right)$ & 1.4 & 0.4 \\
\hline $\mathrm{H}+\mathrm{Al}\left(\mathrm{cmol}_{\mathrm{c}} \mathrm{dm}^{-3}\right)$ & 11.0 & 0.8 \\
\hline Sum of bases $\left(\mathrm{cmol}_{\mathrm{c}} \mathrm{dm}^{-3}\right)$ & 0.6 & 3.3 \\
\hline $\mathrm{t}\left(\mathrm{cmol}_{\mathrm{c}} \mathrm{dm}^{-3}\right)$ & 2.0 & 3.7 \\
\hline $\mathrm{T}\left(\mathrm{cmol}_{\mathrm{c}} \mathrm{dm}^{-3}\right)$ & 11.6 & 4.1 \\
\hline $\mathrm{m}(\%)$ & 70.0 & 10.8 \\
\hline $\mathrm{V}(\%)$ & 5.2 & 80.5 \\
\hline Organic matter $\left(\mathrm{g} \mathrm{kg}^{-1}\right)$ & 37.0 & 39.6 \\
\hline Soil bulk density $\left(\mathrm{mg} \mathrm{m}^{-3}\right)$ & 0.95 & 0.99 \\
\hline Sand $\left(\mathrm{g} \mathrm{kg}^{-1}\right)$ & 180 & 283 \\
\hline Silt $\left(\mathrm{g} \mathrm{kg}^{-1}\right)$ & 140 & 116 \\
\hline Clay $\left(\mathrm{g} \mathrm{kg}^{-1}\right)$ & 680 & 601 \\
\hline \multicolumn{3}{|l|}{ Water retention capacity } \\
\hline $6 \mathrm{kPa}$ (field capacity) & 0.35 & 0.34 \\
\hline $1,519.5 \mathrm{kPa}(\mathrm{PWP})$ & 0.21 & 0.21 \\
\hline
\end{tabular}

(1)t, effective cation exchange capacity; $\mathrm{T}$, cation exchange capacity at $\mathrm{pH} 7.0$; m, aluminum saturation; $\mathrm{V}$, base saturation; and PWP, permanent wilting point.

Pesq. agropec. bras., Brasília, v.51, n.9, p.1476-1483, set. 2016 DOI: 10.1590/S0100-204X2016000900046 
Soil samples were taken in April 2012, in three soil layers: $0.00-0.05,0.05-0.10$, and $0.10-0.20 \mathrm{~m}$, on the projection of the coffee plant canopy. A composite sample of five subsamples from each plot was analyzed for TOC and total nitrogen by the Walkley-Black and Bremner-Mulvaney methods, respectively (Claessen, 1997), and their respective stocks were calculated with the soil layer and equivalent soil mass methods (De Bona et al., 2006). The soil from a native Cerrado area, adjacent to the experimental area, was considered as reference.

Two soil samples from each layer were collected to determine aggregate stability. These samples were sieved using 8 and $4-\mathrm{mm}$ meshes. The retained soil was analyzed, and, from these unstructured samples, two 50-g subsamples were taken, one to determine moisture level and the other to determine aggregate stability according to Claessen (1997). The mean weight diameter of stable aggregates was calculated as described in Netto et al. (2009) and Coutinho et al. (2010).

In March 2012, soil hydrophysical properties were analyzed in unstructured and structured soil samples, collected on the projection of the coffee plant canopy. Structured soil samples were taken with metal rings (50$\mathrm{mm}$ diameter and 51-mm height) for determining soil bulk density and water retention capacity (Costa et al., 2008) in the soil-water tensions of 1, 3, 6, 10, 33, 60, 100 , and $1,500 \mathrm{kPa}$. The soil-water retention curve was adjusted according to the model (Genuchten, 1980),

$$
\theta=\theta_{\mathrm{r}}+\left\{\left(\theta_{\mathrm{s}}-\theta_{\mathrm{r}}\right) /\left[1+\left(\alpha \psi_{\mathrm{m}}\right)^{\mathrm{n}}\right]^{\mathrm{m}}\right\},
$$

in which: $\theta$ is the soil water content $\left(\mathrm{m}^{3} \mathrm{~m}^{-3}\right) ; \theta_{\mathrm{s}}$ is the saturated soil water content $\left(\mathrm{m}^{3} \mathrm{~m}^{-3}\right) ; \theta_{\mathrm{r}}$ is the residual water content $\left(\mathrm{m}^{3} \mathrm{~m}^{-3}\right) ; \psi_{\mathrm{m}}$ is the soil water matric potential $(\mathrm{kPa})$; and $\alpha, \mathrm{m}$, and $\mathrm{n}$ are the empirical parameters of the equation, obtained with the NLIN procedure of the SAS software, version 9.2 (SAS Institute Inc., Cary, NC, USA). Soil texture was determined with the pipette method, in the unstructured sampled soil (Claessen, 1997).

Soil water availability was obtained from total available water (TAw) and readily-available water (RAw), with the expressions: Taw $=\theta_{6}-\theta_{1,500}$ and RAw $=\theta_{6}-\theta_{100}$, in which $\theta_{6}, \theta_{100}$, and $\theta_{1,500}$ are the volumetric moisture at the matric potential of 6,100 , and $1,500 \mathrm{kPa}$, respectively.
Pore size determination was based on Resck et al. (2008). The relative distribution of pore size was calculated by separating the pores according to their diameter, as: macropores, micropores with low-water retention, remaining micropores, and cryptopores (Rocha et al., 2014).

The experiment was carried out in a randomized complete block design, with a split-split-plot arrangement and four replicates, considering water regimes as the main plot, inter-row management systems as the subplot, and soil layers as the sub-subplots. Data normality was checked with the Shapiro-Wilk test, followed by analysis of variance (Anova), and Tukey's test was used to compare the means, at 5\% probability. The effects of water regimes and inter-row management systems on soil attributes were evaluated with principal component analysis (PCA). Statistical analyzes were carried out using PCA with XLSTAT 2014 (Addinsoft, New York, NY, USA) and the SAS software, version 9.2 (SAS Institute Inc., Cary, NC, USA).

\section{Results and Discussion}

Treatments did not differ as to total available water, soil density, and soil $\mathrm{C} / \mathrm{N}$ ratio. However, significant effects of the inter-row management system were observed on micropores of low-water retention and on readilyavailable water. Differences were also significant among soil layers for remaining micropores and total nitrogen stock. For macropores, significant differences were found for water regimes and for inter-row management systems (Table 2). In addition, significant interactions were detected between water regimes and soil layers for total porosity, cryptopores, TOC, and carbon stock. There were also significant interactions between water regimes and inter-row management systems for yield, besides a triple significant interaction among water regimes, inter-row management systems, and soil layers for the mean weight diameter of soil aggregates (Tables 3,4 , and 5).

Irrigation decreased macropores in $9.8 \%$ and covered inter-row in 4.9\% (Table 2). These decreases enhance soil-water retention capacity and, as long as they do not negatively affect soil aeration, they are beneficial for water use efficiency and conservation. In the experimental area, the soil had total porosity of $0.61 \mathrm{~m}^{3} \mathrm{~m}^{-3}$ and average volume of macropores of $0.21 \mathrm{~m}^{3} \mathrm{~m}^{-3}$, considered a good aeration level according to Rodrigues et al. (2011). 
Growing brachiaria in the inter-rows of coffee plants increased the fraction of micropores with low-water retention from 17.6 to $20.1 \%$, when compared with the traditional system without the forage. This represented a significant increase of $18.2 \%$ in the readily-available water (Table 2). These results agree with those reported by Rocha et al. (2014), which attribute them to the aggregating action of the brachiaria root system. However, the remaining micropores were not affected by water regime and inter-row management. Despite this, they were differentiated in the soil layers: the top layer, from 0.00 to $0.05 \mathrm{~m}(\mathrm{~A})$, differed significantly from the next two layers from 0.05 to $0.10 \mathrm{~m}(\mathrm{~B})$ and from 0.10 to $0.20 \mathrm{~m}(\mathrm{C})$, but without any effect on soil water storage.

Significant differences were observed in total nitrogen and nitrogen stock in the soil, when comparing layer $\mathrm{C}$ to the other ones (Table 2). Total nitrogen decreased from soil layer $\mathrm{A}$ to $\mathrm{C}$, from 1.88 to $1.63 \mathrm{~g} \mathrm{~kg}^{-1}$. Actually, the nitrogen stock in the top 0.10 $\mathrm{m}$ of soil, i.e., layers A and B (1.74 $\left.\mathrm{Mg} \mathrm{ha}^{-1}\right)$ was $13 \%$ higher than that of the following $0.10 \mathrm{~m}$, that is, layer C (1.54 Mg ha-1). According to Rangel \& Silva (2007), soil nitrogen stocks are mainly controlled by climatic conditions and vegetation cover, and the introduction of new species with great biomass production capacity can benefit soil nitrogen storage (Mielniczuk et al., 2003), particularly on the top soil layers that are more exposed to climate and management practices.

The irrigated regime increased productivity in both inter-row management systems (Table 3), whereas the rainfed regime decreased production, due to brachiaria competition with coffee plants. It should be noted that irrigation increased productivity in 47.1 and 33.3 bags per hectare, respectively, when compared to the rainfed condition with and without brachiaria in the inter-rows. These results indicate an outstanding effect of irrigation on coffee productivity, which agrees with Bonomo et al. (2008). Regarding the inter-row management systems, the presence of brachiaria increased coffee productivity in $10 \%$, in the irrigated treatment, and reduced it in $42 \%$, in the rainfed one, due to severe competition for water and nutrients.

Water regimes and soil layers interacted regarding total porosity, cryptopores, TOC, and carbon stock (Table 4). Irrigation was the major factor affecting total porosity, with significant difference of $-7 \%$ between soil layers A and C. Furthermore, significant differences, also of $-7 \%$, occurred between the A layers of the irrigated and rainfed treatments. This indicates that soil surface layers of irrigated crops are highly susceptible to soil compaction.

Irrigation had a direct effect on the cryptopore fraction (Table 4). In layer A, it reduced in 12.5\% from rainfed to irrigated regimes. Moreover, the differences in cryptopores between layers A and B amounted to 7.5\% . According to Tognon et al. (1997), cryptopores are the intra-aggregate pores in non-anthropized soils, and changes found in pore size distribution result from the arrangement of these aggregates. The results of the present work indicate that, in agricultural soils, irrigation is an important factor directly affecting the presence of cryptopores.

TOC was higher in the top $0.10-\mathrm{m}$ soil layer of the irrigated plots (Table 4). However, differences were

Table 2. Main effects of water regimes, management systems, and soil layers on the chemical and hydrophysical attributes of a Latossolo Vermelho distrófico típico, i.e., a Typic Haplustox, planted with coffee (Coffea arabica) ${ }^{(1)}$.

\begin{tabular}{|c|c|c|c|c|c|c|c|}
\hline \multirow[t]{2}{*}{ Attribute $^{(2)}$} & \multicolumn{2}{|c|}{ Water regime } & \multicolumn{2}{|c|}{ Management system } & \multicolumn{3}{|c|}{ Soil layer } \\
\hline & Irrigated & Rainfed & $\begin{array}{c}\text { Brachiaria } \\
\text { (Urochloa decumbens) }\end{array}$ & Traditional & $0.00-0.05 \mathrm{~m}$ & $0.05-0.10 \mathrm{~m}$ & $0.10-0.20 \mathrm{~m}$ \\
\hline Ds $\left(\mathrm{mg} \mathrm{m}^{-3}\right)$ & $0.93 \mathrm{a}$ & $0.95 \mathrm{a}$ & $0.94 \mathrm{a}$ & $0.94 \mathrm{a}$ & $0.94 \mathrm{a}$ & $0.93 \mathrm{a}$ & $0.95 \mathrm{a}$ \\
\hline TAw $\left(\mathrm{m}^{3} \mathrm{~m}^{-3}\right)$ & $0.16 \mathrm{a}$ & $0.15 \mathrm{a}$ & $0.16 \mathrm{a}$ & $0.15 \mathrm{a}$ & $0.16 \mathrm{a}$ & $0.15 \mathrm{a}$ & $0.15 \mathrm{a}$ \\
\hline RAw $\left(\mathrm{m}^{3} \mathrm{~m}^{-3}\right)$ & $0.12 \mathrm{a}$ & $0.12 \mathrm{a}$ & $0.13 \mathrm{a}$ & $0.11 b$ & $0.12 \mathrm{a}$ & $0.12 \mathrm{a}$ & $0.12 \mathrm{a}$ \\
\hline $\operatorname{Mac}(\%)$ & $33.70 \mathrm{~b}$ & $37.00 \mathrm{a}$ & $34.50 \mathrm{~b}$ & $36.20 \mathrm{a}$ & $34.30 \mathrm{a}$ & $36.30 \mathrm{a}$ & $35.30 \mathrm{a}$ \\
\hline $\operatorname{Mib}(\%)$ & $19.10 \mathrm{a}$ & $18.50 \mathrm{a}$ & $20.10 \mathrm{a}$ & $17.60 \mathrm{~b}$ & $18.70 \mathrm{a}$ & $18.40 \mathrm{a}$ & $19.50 \mathrm{a}$ \\
\hline Mir (\%) & $5.22 \mathrm{a}$ & $5.70 \mathrm{a}$ & $5.57 \mathrm{a}$ & $5.35 \mathrm{a}$ & $6.28 \mathrm{a}$ & $5.41 \mathrm{ab}$ & $4.68 b$ \\
\hline $\mathrm{TN}\left(\mathrm{g} \mathrm{kg}^{-1}\right)$ & $1.76 \mathrm{a}$ & $1.78 \mathrm{a}$ & $1.78 \mathrm{a}$ & $1.77 \mathrm{a}$ & $1.88 \mathrm{a}$ & $1.81 \mathrm{a}$ & $1.63 \mathrm{~b}$ \\
\hline Nsto $\left(\mathrm{Mg} \mathrm{ha}^{-1}\right)$ & $1.09 \mathrm{a}$ & $1.08 \mathrm{a}$ & $1.10 \mathrm{a}$ & $1.08 \mathrm{a}$ & $0.87 b$ & $0.87 b$ & $1.54 \mathrm{a}$ \\
\hline $\mathrm{C}: \mathrm{N}$ ratio & $15.54 \mathrm{a}$ & $14.80 \mathrm{a}$ & $14.91 \mathrm{a}$ & $15.43 \mathrm{a}$ & $15.25 \mathrm{a}$ & $15.27 \mathrm{a}$ & $15.00 \mathrm{a}$ \\
\hline
\end{tabular}

${ }^{(1)}$ Means followed by equal letters do not differ by Tukey's test, at 5\% probability. ${ }^{(2)}$ Ds, soil density; TAw, total available water; RAw, readily-available water; Mac, macroporosity; Mib, low-retention micropores; Mir, remaining micropores; TN, total nitrogen; Nsto, nitrogen stock; and C:N, carbon:nitrogen ratio. 
significant only in the B layer, in which organic carbon increased from $25.58 \mathrm{~g} \mathrm{~kg}^{-1}$, in the rainfed treatment, to $29.32 \mathrm{~g} \mathrm{~kg}^{-1}$ in the irrigated plots. This $15 \%$ increase was probably due to irrigation effects on the root system distribution of brachiaria and coffee plants, as well as to the greater production of organic residues in the irrigated plots. Considering layers $\mathrm{A}$ and $\mathrm{B}$, average TOC in irrigated plots increased $24 \%$, in comparison to layer $\mathrm{C}$; however, in the rainfed treatments, no significant differences were observed between soil layers. In general, about $50 \%$ TOC was stored in the top $0.10 \mathrm{~m}$ of soil. This result agrees with Rangel et al. (2008).

The behavior of carbon stocks in relation to water regime and soil layers was similar to that observed for TOC (Table 4). Significant differences were only found in the B layer that showed a $15 \%$ increase in carbon stocks under irrigation, compared to rainfed conditions. Carbon stock in the top $0.10 \mathrm{~m}$ represented 46 and $54 \%$ of the total stock from 0.00 to $0.30 \mathrm{~m}$, in rainfed and irrigated treatments, respectively. The total amounts and the relative distribution of organic carbon in the soil profile can be affected by soil class, water deficit intensity, and management system (De Bona et al., 2006). However, in perennial crops like coffee, in which the soil is hardly disturbed, there is a tendency for organic matter preservation in the top

Table 3. Interaction effects of water regime and management system on coffee (Coffea arabica) productivity, expressed in benefited bags $(60 \mathrm{~kg})$ per hectare for the $2010 / 2011$ and 2012/2013 biennia $^{(1)}$.

\begin{tabular}{lcc}
\hline Management system & \multicolumn{2}{c}{ Water regime } \\
\cline { 2 - 3 } & Irrigated & Rainfed \\
\hline Brachiaria (Urochloa decumbens) & $65.8 \mathrm{aA}$ & $18.7 \mathrm{bB}$ \\
Traditional & $59.8 \mathrm{aA}$ & $26.5 \mathrm{bA}$ \\
\hline
\end{tabular}

${ }^{(1)}$ Means followed by equal letters, lowercase in the lines and uppercase in the columns, do not differ by Tukey's test, at $1 \%$ probability. soil layers, where most of the root system of the coffee trees is found.

In the present study, carbon stock in the top $0.20-\mathrm{m}$ soil layer averaged $49.5 \mathrm{Mg} \mathrm{ha}^{-1}$, in the coffee tree canopy projection. This value is $28 \%$ higher than the one reported by Silva et al. (2013), in a Typic Haplustox cultivated with 'Catuaí' coffee trees. The difference of 10.7 $\mathrm{Mg} \mathrm{ha}^{-1}$ between studies can be partially explained by the presence of brachiaria for seven years before the installation of this experiment.

Table 5 presents a triple interaction of the mean weighted diameter of soil aggregates, which increased $33 \%$ in soil layer A with irrigation and brachiaria in the inter-rows, in comparison to the rainfed plots. However, the lack of inter-row cultivation with brachiaria negatively affected aggregate stability, decreasing mean weight diameter in $28 \%$. This allows to compare the aggregation state of different types of soils and soil layers (Kato et al., 2010). Since the effect of soil management on aggregate stability is mainly controlled by the size of aggregates, decreases in stability indicate a deleterious effect of the management system on soil structure (Souza et al., 2004).

Under irrigation, brachiaria increased the mean weight diameter by $34 \%$ (Table 5), an evidence of the positive effect of this treatment on the stability of aggregates. However, the presence of the forage in the rainfed treatments decreased this attribute in $27 \%$. Analogously, considering each soil layer in relation to the water regime and management system, layer B had a $27 \%$ higher mean weight diameter than the top soil layer $\mathrm{A}$, in the irrigated treatment without brachiaria planted in the inter-rows. This indicates a loss of aggregate stability in the $0.05-\mathrm{m}$ layer, probably due to the direct exposure of the top soil to management practices, since this result was not observed with the presence of brachiaria. In this regard, grasses have a strong, abundant root system that, upon decomposition,

Table 4. Interaction effects of water regime and soil layer on total soil porosity (TP), fraction of cryptopores, total organic carbon (TOC), and carbon stock (Csto) in a Latossolo Vermelho distrófico típico, i.e., a Typic Haplustox, planted with coffee $(\text { Coffea arabica })^{(1)}$.

\begin{tabular}{|c|c|c|c|c|c|c|c|c|}
\hline \multirow[t]{2}{*}{ Soil layer ${ }^{(2)}$} & \multicolumn{2}{|c|}{$\mathrm{TP}\left(\mathrm{m}^{3} \mathrm{~m}^{-3}\right)$} & \multicolumn{2}{|c|}{ Cryptopores (\%) } & \multicolumn{2}{|c|}{ TOC $\left(\mathrm{g} \mathrm{kg}^{-1}\right)$} & \multicolumn{2}{|c|}{ Csto $\left(\mathrm{Mg} \mathrm{ha}^{-1}\right)$} \\
\hline & Irrigated & Rainfed & Irrigated & Rainfed & Irrigated & Rainfed & Irrigated & Rainfed \\
\hline A & $0.59 \mathrm{bB}$ & $0.63 \mathrm{aA}$ & $43.05 \mathrm{aA}$ & $38.26 \mathrm{bA}$ & $28.93 \mathrm{aA}$ & $27.83 \mathrm{aA}$ & $12.29 \mathrm{aB}$ & $11.83 \mathrm{aB}$ \\
\hline B & $0.62 \mathrm{aAB}$ & $0.62 \mathrm{aA}$ & $40.02 \mathrm{aB}$ & $39.83 \mathrm{aA}$ & $29.32 \mathrm{aA}$ & $25.58 \mathrm{bA}$ & $13.20 \mathrm{aB}$ & $11.52 \mathrm{bB}$ \\
\hline $\mathrm{C}$ & $0.63 \mathrm{aA}$ & $0.62 \mathrm{aA}$ & $42.89 \mathrm{aAB}$ & $38.10 \mathrm{bA}$ & $23.44 \mathrm{aB}$ & $25.28 \mathrm{aA}$ & $22.03 \mathrm{aA}$ & $27.77 \mathrm{aA}$ \\
\hline
\end{tabular}

${ }^{(1)}$ Means followed by equal letters, lowercase in the lines and uppercase in the columns, do not differ by Tukey's test, at $1 \%$ probability. ${ }^{(2)} \mathrm{A}$, layer of $0.00-0.05$-m soil depth; B, layer of 0.05-0.10-m soil depth; and C, layer of 0.10-0.20-m soil depth. 
can release nutrients and help the buildup of soil organic matter, contributing significantly to soil aggregation (Mielniczuk et al., 2003).

In the rainfed treatments, the presence of brachiaria increased mean weight diameter from 0.05 to 0.20 $m$ depth (Table 5), which might have been caused by an increase in root depth, in response to water deficit. However, a decrease in the attribute was verified in soil layer C (\%) without brachiaria, compared to soil layers A (33\%) and B (24\%).

In the irrigated plots, brachiaria cultivation in the inter-rows had a positive effect on aggregate stability, as reflected by the mean weight diameter $(4.64 \mathrm{~mm})$ in all soil layers (Table 6), which was similar to the one registered on the undisturbed Cerrado area $(4.65 \mathrm{~mm})$. This highlights the aggregating effect of the brachiaria roots on restructuring soil. The average mean weight diameter of layers $\mathrm{A}$ and $\mathrm{C}$, for this same treatment, was higher $(4.75 \mathrm{~mm})$ than the ones observed in the Cerrado (4.60 mm).

A clear interaction effect of irrigation and brachiaria presence on soil aggregation was found, considering the parameters related to soil water storage. Two principal components (PC1 and PC2) were generated as tools to reveal the effects of water regimes and inter- row management systems on mean weight diameter, as well as of its impacts on readily-available water, macropores, and low-water retention micropores. The factorial charges for these variables are shown in Table 7. For the distribution of the selected variables over the soil layers, a cumulative variance of $77.91 \%$ was observed, resulting from the sum of PC1 and PC2 for the variables mean weight diameter, lowwater retention micropores, macropores, and readilyavailable water. However, PC1 was responsible for $53.05 \%$ of the variance, distinguishing the coordinates into two groups: irrigated system with brachiaria as cover crop and rainfed traditional system (Figure 1).

These results support previous discussions related to the absolute values of the analyzed variables, especially for water storage. Macroporosity was favored in the rainfed traditional system (without brachiaria), indicating less structure for soil water storage; however, the soil water storage capacity, evaluated by readilyavailable water and low-water retention micropores, was enhanced in the irrigated treatment with brachiaria due to an improved soil aggregation (mean weight diameter). The vector directions in Figure 1 show that, from the selected variables, only macropores were placed in the quadrant closely related to the rainfed

Table 5. Interaction effects of water regime (irrigated and rainfed), management system, and soil layer on mean weight diameter of pores $(\mathrm{mm})$, in a Latossolo Vermelho distrófico típico, i.e., a Typic Haplustox, planted with coffee (Coffea arabica $)^{(1)}$.

\begin{tabular}{lccc}
\hline Soil layer $(\mathrm{m})^{(2)}$ & \multicolumn{2}{c}{ Irrigated } & \multicolumn{2}{c}{ Rainfed } \\
\cline { 2 - 4 } & $\begin{array}{c}\text { Brachiaria } \\
\text { (Urochloa decumbens) }\end{array}$ & Traditional & Brachiaria \\
(Urochloa decumbens)
\end{tabular}

${ }^{(1)}$ Means followed by the equal letters, lowercase in the comparison between water regimes (WR), Greek letter in the comparison between management systems within WR, and uppercase in the columns, do not differ by Tukey's test, at 5\% probability. ${ }^{(2)} \mathrm{A}$, layer of $0.00-0.05-\mathrm{m}$ soil depth; B, layer of $0.05-0.10$-m soil depth; and C, layer of $0.10-0.20-\mathrm{m}$ soil depth.

Table 6. Mean \pm standard deviation of the chemical and hydrophysical attributes of a pristine Cerrado (Brazilian savanna) soil, adjacent to the experimental area, used as reference ${ }^{(1)}$.

\begin{tabular}{|c|c|c|c|c|c|c|}
\hline \multirow[t]{2}{*}{ Soil layer ${ }^{(2)}$} & \multirow{2}{*}{$\begin{array}{l}\text { MWD } \\
(\mathrm{mm})\end{array}$} & TOC & $\mathrm{TN}$ & \multirow[t]{2}{*}{ C:N ratio } & \multirow{2}{*}{\multicolumn{2}{|c|}{ Csto $\left(\mathrm{Mg} \mathrm{ha}^{-1}\right)$}} \\
\hline & & --------------------- & --------------. & & & \\
\hline A & $4.73 \pm 0.27$ & $34.75 \pm 2.09$ & $2.66 \pm 0.20$ & $13.06 \pm 1.08$ & 13.59 & 1.24 \\
\hline B & $4.74 \pm 0.24$ & $29.34 \pm 1.73$ & $2.22 \pm 0.31$ & $13.35 \pm 2.01$ & 14.17 & 1.06 \\
\hline $\mathrm{C}$ & $4.48 \pm 0.19$ & $31.29 \pm 4.29$ & $2.01 \pm 0.18$ & $15.50 \pm 1.28$ & 28.29 & 1.89 \\
\hline Mean & 4.65 & 31.79 & 2.30 & 13.97 & $56.05^{(3)}$ & $4.19^{(3)}$ \\
\hline
\end{tabular}

${ }^{(1)} \mathrm{MWD}$, mean weight diameter; TOC, total organic carbon; TN, total soil nitrogen; C:N, carbon:nitrogen ratio; Csto, carbon stock; and Nsto, nitrogen stock. ${ }^{(2)} \mathrm{A}$, layer of $0.00-0.05-\mathrm{m}$ soil depth; B, layer of $0.05-0.10-\mathrm{m}$ soil depth; and C, layer of $0.10-0.20$-m soil depth. ${ }^{(3)}$ Total stock up to 0.20 -m soil depth. 
treatment. However, the variables associated to soil water storage (readily-available water and low-water retention micropores) and to soil aggregation state (mean weight diameter) were positioned on the opposite quadrants, linked to irrigated treatments with brachiaria. Therefore, the use of brachiaria as cover crop, associated with coffee crop irrigation, in the Cerrado region, enabled the accumulation of soil organic matter, favoring its aggregation state (Portella et al., 2012), which increased water storage capacity.

Table 7. Factorial charges of different variables associated with the principal components (PC) of the soil sampled both in the inter-rows of coffee (Coffea arabica) trees planted with Brachiaria (Urochloa decumbens) subjected to irrigation, and in the inter-rows under the traditional management with a rainfed water regime.

\begin{tabular}{lccc}
\hline Attribute $^{(1)}$ & PC1 & PC2 & PC3 \\
\hline RAw & 0.767 & 0.551 & 0.075 \\
Mac & -0.625 & 0.556 & 0.536 \\
Mib & 0.879 & 0.292 & -0.084 \\
MWD & 0.608 & -0.545 & 0.578 \\
\hline
\end{tabular}

(1)RAw, readily-available water; Mac, fraction of macropores; Mib, low-retention micropores; and MWD, mean weight diameter.

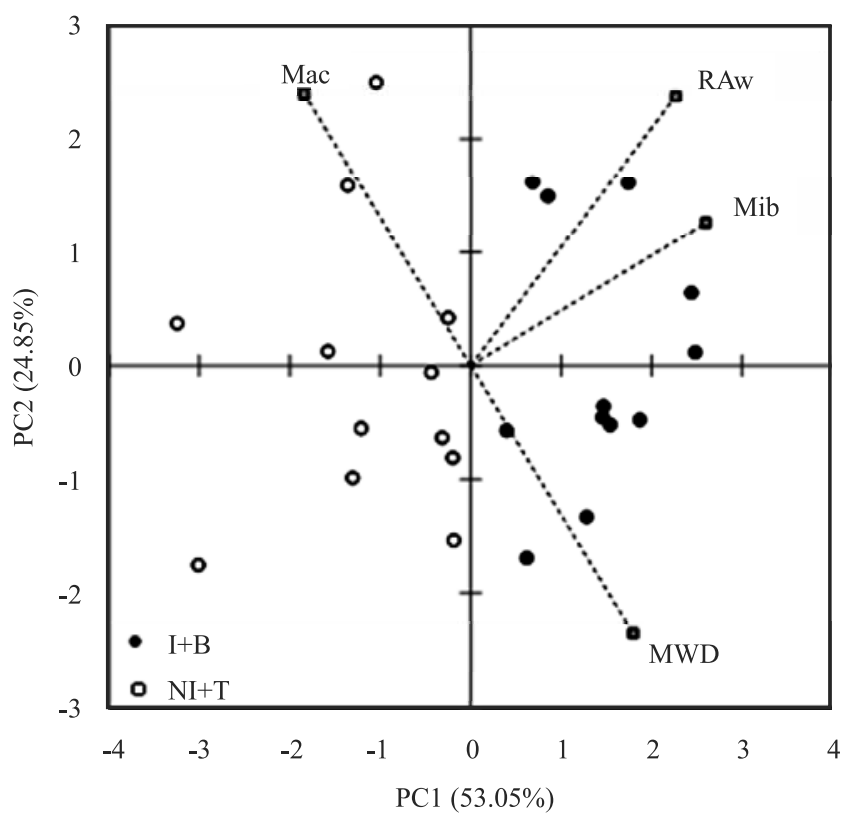

Figure 1. Ordination diagram for the variables: Mac, macroporosity; RAw, readily-available water; Mib, lowretention microporosity; and MWD, mean weight diameter of soil aggregates generated from the comparison of irrigated brachiaria (Urochloa decumbens) treatments (I+B) and rainfed traditional treatments $(\mathrm{NI}+\mathrm{T})$.

\section{Conclusions}

1. In the Cerrado region, the association of irrigation and brachiaria (Urochloa decumbens) in the coffee (Coffea arabica) crop inter-rows favors several soil chemical and hydrophysical attributes, improving soil structure and its water storage capacity, and also improves the mean weight diameter of soil aggregates.

2. The irrigated water regime affects total soil porosity, macroporosity, and cryptoporosity, besides the location of total organic carbon on the soil profile, favoring the stock on soil surface layers.

3. The coffee crop intercropped with brachiaria increases the fraction of readily-available water due to an increased number of low-retention micropores in the soil.

4. In rainfed coffee crop with brachiaria in the interrows, the forage may compete severely with coffee trees, drastically reducing their productivity.

\section{Acknowledgments}

To Consórcio Pesquisa Café and to Empresa Brasileira de Pesquisa Agropecuária (project No. 02.13.02.003.00.02), for financial support.

\section{References}

ACOMPANHAMENTO DA SAFRA BRASILEIRA [DE] CAFÉ: safra 2014: quarto levantamento, Brasília, DF, v.1, n.3, dez. 2014. 51p.

BICALHO, I.M. Alteração na agregação e carbono orgânico total em solo cultivado com café sob diferentes sistemas de manejo. Enciclopédia Biosfera, v.7, p.1-14, 2011.

BONOMO, R.; OLIVEIRA, L.F.C. de; SILVEIRA NETO, A.N.; BONOMO, P. Produtividade de cafeeiros arábica irrigados no Cerrado goiano. Pesquisa Agropecuária Tropical, v.38, p.233$240,2008$.

CLAESSEN, M.E.C. (Org.). Manual de métodos de análise de solo. 2.ed. rev. atual. Rio de Janeiro: Embrapa-CNPS, 1997. 212p. (Embrapa-CNPS. Documentos, 1).

COSTA, A.R. da; SATO, J.H.; RAMOS, M.L.G.; FIGUEIREDO, C.C. de; SOUZA, G.P. de; ROCHA, O.C.; GUERRA, A.F. Microbiological properties and oxidizable organic carbon fractions of an Oxisol under coffee with split phosphorus applications and irrigation regimes. Revista Brasileira Ciência do Solo, v.37, p.5565, 2013. DOI: 10.1590/S0100-06832013000100006.

COSTA, W.A.; OLIVEIRA, C.A. da S.; KATO, E. Modelos de ajuste e métodos para a determinação da curva de retenção de água de um Latossolo-Vermelho-Amarelo. Revista Brasileira de Ciência do Solo, v.32, p.515-523, 2008. DOI: 10.1590/S010006832008000200006.

COUTINHO, F.S.; LOSS, A.; PEREIRA, M.G.; RODRIGUES JUNIOR, D.J.; TORRES, J.L.R. Estabilidade de agregados e 
distribuição do carbono em Latossolo sob sistema plantio direto em Uberaba, Minas Gerais. Comunicata Scientiae, v.1, p.100105,2010 .

DE BONA, F.D.; BAYER, C.; BERGAMASCHI, H.; DIECKOW, J. Carbono orgânico no solo em sistemas irrigados por aspersão sob plantio direto e preparo convencional. Revista Brasileira de Ciência do Solo, v.30, p.911-920, 2006. DOI: 10.1590/S010006832006000500017.

EBERHARDT, D.N.; VENDRAME, P.R.S.; BECQUER, T.; GUIMARÃES, M. de F. Influência da granulometria e da mineralogia sobre a retenção de fósforo em Latossolos sob pastagens no Cerrado. Revista Brasileira de Ciência do Solo, v.32, p.1009-1016, 2008. DOI: 10.1590/S0100-06832008000300010.

GENUCHTEN, M.Th. van. A closed-form equation for predicting the hydraulic conductivity of unsaturated soils. Soil Science Society of America Journal, v.44, p.892-898, 1980. DOI: 10.2136/ sssaj1980.03615995004400050002x.

GUERRA, A.F.; ROCHA, O.C.; RODRIGUES, G.C.; SANZONOWICZ, C.; RIBEIRO FILHO, G.C.; TOLEDO, P.M. dos R.; RIBEIRO, L.F. Sistema de produção de café irrigado: um novo enfoque. Item: Irrigação e Tecnologia Moderna, v.73, p.52-61, 2007.

KATO, E.; RAMOS, M.L.G.; VIEIRA, D. de F.A.; MEIRA, A.D.; MOURÃO, V.C. Propriedades físicas e teor de carbono orgânico de um Latossolo Vermelho-Amarelo do Cerrado, sob coberturas vegetais. Bioscience Journal, v.26, p.732-738, 2010.

LIMA, L.A.; CUSTÓDIO, A.A. de P.; GOMES, N.M. Produtividade e rendimento do cafeeiro nas cinco primeiras safras irrigado por pivô central em Lavras, MG. Ciência e Agrotecnologia, v.32, p.2560-2568, 2008. DOI: 10.1590/S1413-70542008000600023.

MAGALHÃES, C.E.O.; RONCHI, C.P.; RUAS, R.A.A.; SILVA, M.A.A.; ARAÚJO, F.C.; ALMEIDA, W.L. Seletividade e controle de plantas daninhas com oxyfluorfen e sulfentrazone na implantação de lavoura de café. Planta Daninha, v.30, p.607-616, 2012. DOI: 10.1590/S0100-83582012000300017.

MIELNICZUK, J.; BAYER, C.; VEZZANI, F.M.; LOVATO, T.; FERNANDES, F.F.; DEBARBA, L. Manejo de solo e culturas e sua relação com os estoques de carbono e nitrogênio do solo. In: CURI, N.; MARQUES, J.J.; GUILHERME, L.R.G.; LIMA, J.M. de; LOPES, A.S.; ALVAREZ V., V.H. Tópicos em ciência do solo. Viçosa: Sociedade Brasileira de Ciência do Solo, 2003. v.3, p.209248.

NETTO, I.T.P.; KATO, E.; GOEDERT, W.J. Atributos físicos e químicos de um Latossolo Vermelho-Amarelo sob pastagens com diferentes históricos de uso. Revista Brasileira de Ciência do Solo, v.33, p.1441-1448, 2009. DOI: 10.1590/S010006832009000500034.

NUNES, L.A.P.L.; DIAS, L.E.; JUCKSCH, I.; BARROS, N.F. de. Atributos físicos do solo em área de monocultivo de cafeeiro na Zona da Mata de Minas Gerais. Bioscience Journal, v.26, p.71-78, 2010.

PORTELLA, C.M.R.; GUIMARÃES, M. de F.; FELLER, C.; FONSECA, I.C. de B.; TAVARES FILHO, J. Soil aggregation under different management systems. Revista Brasileira de Ciência do Solo, v.36, p.1868-1877, 2012. DOI: 10.1590/S010006832012000600021.

RANGEL, O.J.P.; SILVA, C.A. Estoques de carbono e nitrogênio e frações orgânicas de Latossolo submetido a diferentes sistemas de uso e manejo. Revista Brasileira de Ciência do Solo, v.31, p.1609-1623, 2007. DOI: 10.1590/S0100-06832007000600037.

RANGEL, O.J.P.; SILVA, C.A.; GUIMARÃES, P.T.G.; MELO, L.C.A.; OLIVEIRA JUNIOR, A.C. de. Carbono orgânico e nitrogênio total do solo e suas relações com os espaçamentos de plantio de cafeeiro. Revista Brasileira de Ciência do Solo, v.32, p.2051-2059, 2008. DOI: 10.1590/S0100-06832008000500026.

RESCK, D.V.S.; FEREIRA, E.A.B.; SANTOS JUNIOR, J.D.G.; SÁ, M.A.C.; FIGUEIREDO, C.C. Manejo do solo sob um enfoque sistêmico. In: FALEIRO, F.G.; FARIAS NETO, A.L.D. (Ed.). Savanas: desafios e estratégias para o equilíbrio entre sociedade, agronegócio e recursos naturais. Planaltina, DF: Embrapa Cerrados, 2008. p.417-473.

ROCHA, O.C.; GUERRA, A.F.; RAMOS, M.L.G.; OLIVEIRA, A. da S.; BARTHOLO, G.F. Qualidade físico-hídrica de um Latossolo sob irrigação e braquiária em lavoura de café no Cerrado. Coffee Science, v.9, p.516-526, 2014.

RODRIGUES, S.; SILVA, A.P. da; GIAROLA, N.F.B.; ROSA, J.A. Permeabilidade ao ar em Latossolo Vermelho sob diferentes sistemas de manejo. Revista Brasileira de Ciência do Solo, v.35, p.105-114, 2011. DOI: 10.1590/S0100-06832011000100010.

SAKAI, E.; BARBOSA, E.A.A.; SILVEIRA, J.M. de C.; PIRES, R.C. de M. Coffea arabica (cv. Catuaí) production and bean size under different population arrangements and soil water availability. Engenharia Agrícola, v.33, p.145-156, 2013. DOI: 10.1590/ S0100-69162013000100015.

SILVA, A.B. da; MANTOVANI, J.R.; MOREIRA, A.L.; REIS, R.L.N. Estoques de carbono no solo e em plantas de cafeeiro (Coffea arabica L.). Interciencia, v.38, p.286-291, 2013.

SIQUEIRA, R.H. da S.; FERREIRA, M.M.; ALCÂNTARA, E.N. de; CARVALHO, R.C. da S. Atributos químicos de um Latossolo submetido a diferentes controles de plantas invasoras em cafeeiros. Coffee Science, v.10, p.138-148, 2015.

SOUZA, Z.M. de; MARQUES JÚNIOR, J.; PEREIRA, G.T. Variabilidade espacial da estabilidade de agregados e matéria orgânica em solos de relevos diferentes. Pesquisa Agropecuária Brasileira, v.39, p.491-499, 2004. DOI: 10.1590/S0100204X2004000500012.

TOGNON, A.A.; DEMATTÊ, J.A.M.; MAZZA, J.A. Alterações nas propriedades químicas de Latossolos roxos em sistemas de manejo intensivos e de longa duração. Revista Brasileira de Ciência do Solo, v.21, p.271-278, 1997.

WUTKE, E.B.; CALEGARI, A.; WILDNER, L. do P. Espécies de adubos verdes e plantas de cobertura e recomendações para uso. In: LIMA FILHO, O.F. de; AMBROSANO, E.J.; ROSSI, F.; CARLOS, J.A.D. (Ed.). Adubação verde e plantas de cobertura no Brasil: fundamentos e prática. Brasília: Embrapa, 2014. v.1, p.59-168.

Received on August 31, 2015 and accepted on February 24, 2016

Pesq. agropec. bras., Brasília, v.51, n.9, p.1476-1483, set. 2016 DOI: 10.1590/S0100-204X2016000900046 